\title{
Nutritional and Income Security through Backyard Poultry Farming
}

\author{
Pushp Gautam ${ }^{1}$, M. K. Barnwal ${ }^{2}$ and B. K. Jha $^{3 *}$, Shweta Kumari ${ }^{3}$ and AnupKumar ${ }^{3}$ \\ ${ }^{1} C A B M, B A U$, Ranchi, India \\ ${ }^{2}$ Department of Plant Pathology, BAU, Ranchi, India \\ ${ }^{3}$ Dept. of Agriculture Extension \& Communication, BAU, Ranchi, India \\ *Corresponding author
}

\section{A B S T R A C T}

\section{Keywords}

Nutritional and Income Security, Backyard Poultry Farming

Article Info

Accepted:

12 January 2021

Available Online:

10 February 2021
A study was conducted to find out impact of backyard poultry on nutritional and income security of farmers. Ranchi district was purposively selected where Jharkhand State Livelihood Promotion Society has been undertaking promotional activities. Ten farmers each from six villages of two blocks were selected randomly, thereby, the sample constituted 60 respondents. Nutritional security was measured through consumption gap in vegetarian food items, consumption of poultry eggs and meat and energy supplement by eggs and poultry meat. Economic analysis was done through computation of gross and net return as well as BCR. Income supplement by backyard poultry farming was also calculated. As far as nutritional security is concerned, per month family consumption gap was found highest in milk and milk product $(22.4 \mathrm{~kg})$ and lowest in sugar $(2.28 \mathrm{~kg})$. Out of per month family calorie gap of $28,81,802 \mathrm{kcal}$, the poultry compensated by $13,2,7000$ kcal. The contribution from backyard poultry towards the mean annual income was $14.84 \%$ and the benefit- cost ratio of backyard was found to be 3.41 . The contribution of backyard poultry towards nutrition and income security was found appreciable which, if, promoted with suitable incentives and extension strategies could ensure the realization of healthy and affluent rural society.

\section{Introduction}

Poultry population has grown spectacularly throughout the world of $23 \%$ in developed and $76 \%$ in developing countries. There is evidence that investments in small-scale poultry farming generates handsome returns and contribute to poverty reduction and increased food security in regions where a large share of the population keeps some poultry birds (Jensen and Dolberg, 2003; Mack, et al., 2005; Pica-ciamarra and Otte,
2010). The increasing productivity of backyard poultry can contribute to alleviating poverty and reducing malnutrition on a broad scale.

India ranks $3^{\text {rd }}$ in egg production in the world (FAO, 2016). The per capita consumption of egg, chicken meat is about 62 eggs and $250 \mathrm{~g}$ respectively per annum in certain areas whereas, fifty eggs and $750 \mathrm{~g}$ chicken meat in rural areas against the recommended level of 180 eggs and $10.25 \mathrm{~kg}$ of meat per annum. On 
an average, landless/marginal/small-scale Indian poultry keeping household, keeps an average flock size of 8 to 12 birds. In India it is estimated that over $50 \%$ of landless and marginal farmers depend on poultry and small ruminant rearing (Jha and Chakrabarti, 2017).

Backyard poultry farming has been found profitable (Ekunwe et al., 2010; Maikasuwa and Jabo, 2011 and Baruah and Raghav, 2017) and contributes towards women empowerment (Gangwar et al., 2013).This has been recognized as an effective tool for poverty alleviation in the rural families(Singh et al., 2020). Backyard poultry farming with improved chicken breed is slowly gaining popularity as a potential tool to alleviate protein hunger and provide subsidiary income among rural and tribal people in the state. Rural backyard poultry contributes nearly $30 \%$ in the national egg production.

\section{Materials and Methods}

Ranchi district was purposively selected as it has highest percentage of backyard poultry farmer and Jharkhand State Livelihood Promotional Society (JSLPS) has been undertaking promotional activities. Two blocks viz. Angara and Silli of Ranchi district were selected on the basis of duration of National Rural Livelihoods Mission (NRLM) Ajeevika project.

Ten farmers each from the selected villages i.e. Paras Toli, BhelwaJara and MaheshpurTungriTola from Angara block and CheetaTanr, Lota and Nawadih from Silli block were selected randomly who were involved in backyard poultry farming. Thus, the sample size constituted 60 respondents.

\section{Results and Discussion}

Results and discussion have been divided into two sections i.e. nutritional security of the farmers and income from backyard poultry farming.

\section{Nutritional security of farmers}

This section deals with nutritional security of farmers and food items consumed by the family members including poultry product to meet the nutritional requirement. Researcher found it difficult to calculate nutritional status and consumption of food items by an individual in a family. Moreover there are certain food items like poultry meat and egg are not consumed on daily basis. Hence, for assessing consumption gaps, per month consumption of food items by whole family was calculated.

\section{Consumption gap in vegetarian food items}

Different types of foods are required for body building and energy yielding. Nutritional experts have recommended the quantity of different food items for different types of lifestyle. The consumption gap of vegetarian food items have been calculated vis-à-vis the recommendation by National Institute of Nutrition (2017) which have been presented in Table 1. and Fig. 1.

It is revealed by the table and fig that the highest per month mean consumption gap in case of respondents' family was found in milk and milk product $(22.4 \mathrm{~kg})$ followed by vegetable $(10.93 \mathrm{~kg})$, cereal and millet $(9.4$ $\mathrm{kg})$, fruits $(5.46 \mathrm{~kg})$, pulses $(4.69 \mathrm{~kg})$, fat and oils $(2.42 \mathrm{~kg})$ and sugar $(2.28 \mathrm{~kg})$. It is to be highlighted that highest standard deviation was found in milk and milk product (10.22) and lowest in sugar (0.90).

The findings led us to conclude that family members of the respondents are not taking food items as per recommendations which may lead to nutritional disorder and infectious disease there by reduction in life expectancy. 
Egg and poultry meat consumption by the respondents

Backyard poultry farming generally ensures nutritional security of the family to some extent. The egg and poultry meat consumption by the family members of respondents, is shown in Table 2 and Fig 2.

Table 2 and Fig 2 indicate that $83 \%$ of the respondents' family members consumed between 12-28 eggs per month followed by more than 28 eggs per month by the respondents' family members and only $7 \%$ of the respondents' family members consumed less than 12 eggs per month. Similarly, $90 \%$ of the respondents' family members consumed $1.5-4.1 \mathrm{~kg}$ of poultry meat per month which was followed by more than 4.1 $\mathrm{kg}$ poultry meat per month by the $10 \%$ respondents' family members.

The findings revealed that the consumption of eggs and meat provide nutritional security of the family members of respondents to some extent, but it is not sufficient.

Table.1 Per month family consumption gaps of the respondents in vegetarian food items

\begin{tabular}{|l|l|c|c|c|}
\hline Sl. No. & \multicolumn{1}{|c|}{ Food groups } & $\begin{array}{c}\text { Range of gap } \\
\text { (in kg) }\end{array}$ & $\begin{array}{c}\text { Mean gap (in } \\
\text { kg) }\end{array}$ & Standard Deviation \\
\hline $\mathbf{1}$ & Cereals \& millets & 20.4 & 9.40 & 6.03 \\
\hline $\mathbf{2}$ & Pulses & 8.4 & 4.69 & 2.15 \\
\hline $\mathbf{3}$ & Milk \& milk products & 39 & 22.40 & 10.22 \\
\hline $\mathbf{4}$ & Vegetables & 20.2 & 10.93 & 5.35 \\
\hline $\mathbf{5}$ & Fruits & 10 & 5.47 & 2.07 \\
\hline $\mathbf{6}$ & Sugar & 4 & 2.29 & 0.9 \\
\hline $\mathbf{7}$ & Fat / Oils (visible) & 3.8 & 2.42 & 1.03 \\
\hline
\end{tabular}

Table.2 Frequency distribution of respondents' family in respect of per month egg and poultry meat consumption $(n=60)$

\begin{tabular}{|c|c|c|c|}
\hline \multicolumn{4}{|c|}{ Consumption of poultry product } \\
\hline & \multicolumn{3}{|c|}{ Consumption/months } \\
\hline $\mathbf{1}$ & Egg (no.) & Frequency & percentage \\
\hline a) & $<12$ & 4 & 7 \\
\hline b) & 12 to 28 & 50 & 83 \\
\hline \multirow[t]{2}{*}{ c) } & $>28$ & 6 & 10 \\
\hline & Mean consumption & \multicolumn{2}{|c|}{20.23} \\
\hline 2 & Chicken $(\mathrm{kg})$ & & \\
\hline a) & $<1.5$ & 0 & 0 \\
\hline b) & 1.5 to 4.1 & 54 & 90 \\
\hline \multirow[t]{2}{*}{ c) } & $>4.1$ & 6 & 10 \\
\hline & Mean consumption & \multicolumn{2}{|c|}{2.83} \\
\hline
\end{tabular}


Table.3 Nutritional security ensured to respondents' family member by the consumption of poultry products

\begin{tabular}{|l|l|c|}
\hline \multicolumn{3}{|c|}{ Nutritional security ensured by the consumption of poultry product } \\
\hline Sl. No. & \multicolumn{1}{|c|}{ Particulars } & Energy (kcal) \\
\hline $\mathbf{1}$ & Actual gap & 2881802 \\
\hline $\mathbf{2}$ & Poultry supplement & 1327000 \\
\hline $\mathbf{3}$ & Final gap & 1554802 \\
\hline
\end{tabular}

Table.4 Fixed assets possessed by the respondents for backyard poultry farming

\begin{tabular}{|c|l|c|c|c|}
\hline Sl. No. & \multicolumn{1}{|c|}{ Asset } & Rate (in Rs.) & Unit & Amount (in Rs.) \\
\hline $\mathbf{1}$ & Bamboo house for 25 birds & 6000 & 1 & 6000 \\
\hline $\mathbf{2}$ & Feeding and watering equipment's & 150 & 3 & 450 \\
\hline \multicolumn{2}{|c|}{ Total } \\
\hline
\end{tabular}

Table.5 Economics of backyard poultry farming of the flock size of 25 birds

\begin{tabular}{|c|c|c|c|c|}
\hline & \multicolumn{4}{|c|}{ Economics of backyard poultry Farming on 25 flock size } \\
\hline $\begin{array}{c}\text { Sl. } \\
\text { No. }\end{array}$ & Particulars & Unit & Rate (in Rs.) & Amount(in Rs.) \\
\hline 1 & \multicolumn{4}{|l|}{ Fixed cost } \\
\hline a) & \multicolumn{3}{|c|}{ Deprecation@25\% on housing cost } & 1500 \\
\hline b) & \multicolumn{3}{|c|}{ Interest@10\% on housing cost } & 600 \\
\hline c) & \multicolumn{3}{|c|}{ Deprecation@25\% on feeding and watering equipment } & 90 \\
\hline d) & \multicolumn{3}{|c|}{ Interest @ $10 \%$ on feeding and watering equipment } & 45 \\
\hline & Total & & & 2235 \\
\hline 2 & Variable cost & & & \\
\hline a) & cost of chicks & 25 No. & 65 & 1625 \\
\hline b) & feeding cost & 5 bag of $40 \mathrm{~kg}$ & 1900 & 9500 \\
\hline \multirow[t]{3}{*}{ c) } & Vaccination & 25 No. & 200 & 200 \\
\hline & \multicolumn{3}{|l|}{ Total } & 11325 \\
\hline & \multicolumn{3}{|l|}{ Grand Total (Rs.) } & 13560 \\
\hline 3 & Return & & & \\
\hline a) & Return from egg & 3375 No. & 10 & 33750 \\
\hline b) & Return from bird & 25 No. & 300 & 7500 \\
\hline c) & Return from poultry manure & 2 cart & 2500 & 5000 \\
\hline d) & \multicolumn{3}{|l|}{ Gross return } & 46250 \\
\hline 4 & \multicolumn{3}{|l|}{ Net return } & 32690 \\
\hline 5 & \multicolumn{3}{|l|}{ Return from per bird } & 1307 \\
\hline 6 & \multicolumn{3}{|l|}{ B.C.R } & 3.41 \\
\hline
\end{tabular}


Table.6 Income contribution from backyard poultry farming

\begin{tabular}{|c|c|c|}
\hline Sl.No. & Particulars & $\begin{array}{c}\text { Return (in } \\
\text { Rs.) }\end{array}$ \\
\hline 1 & Mean income from other sources combined together (in Rs.) & 105800 \\
\hline 2 & Mean Poultry income (in Rs.) & 13700 \\
\hline 3 & Percentage contribution towards total income (in \%) & 14.87 \\
\hline
\end{tabular}

Fig.1 Bar diagram showing consumption gaps of the respondents in vegetarian food items

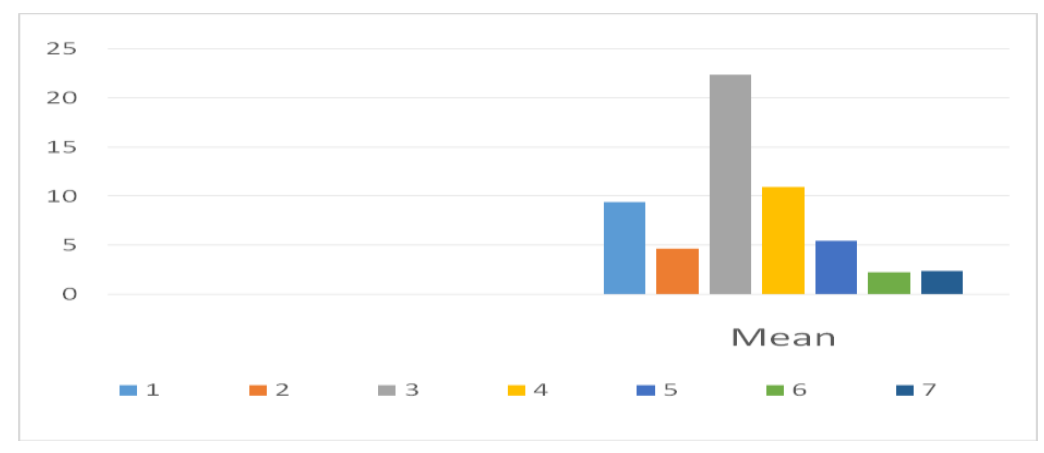

Fig.2 Bar diagram showing per month egg and chicken consumption by the respondents' family

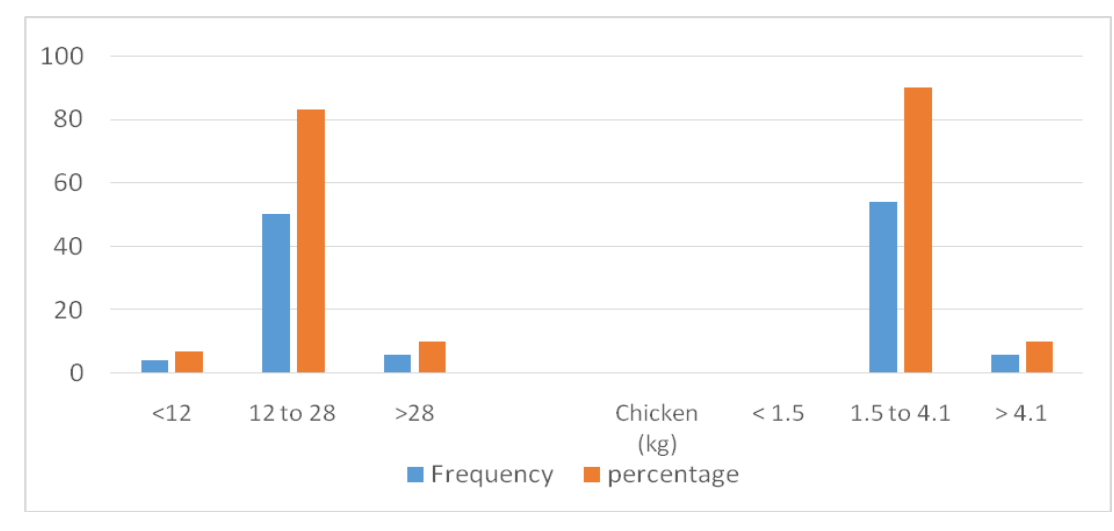

Fig.3 Bar diagram showing nutritional security ensured respondents' family members by poultry product consumption

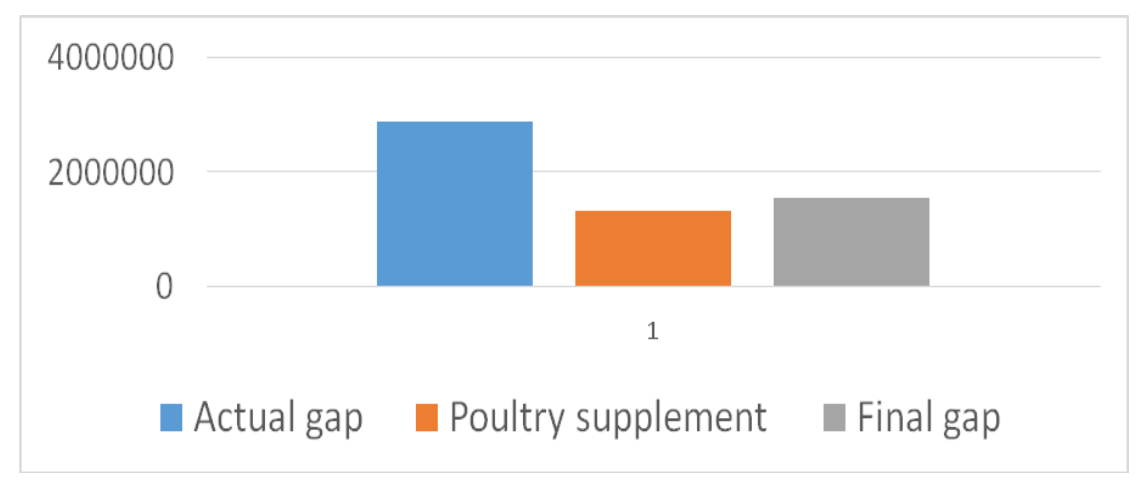


Fig.4 Bar diagram showing mean income of the respondents

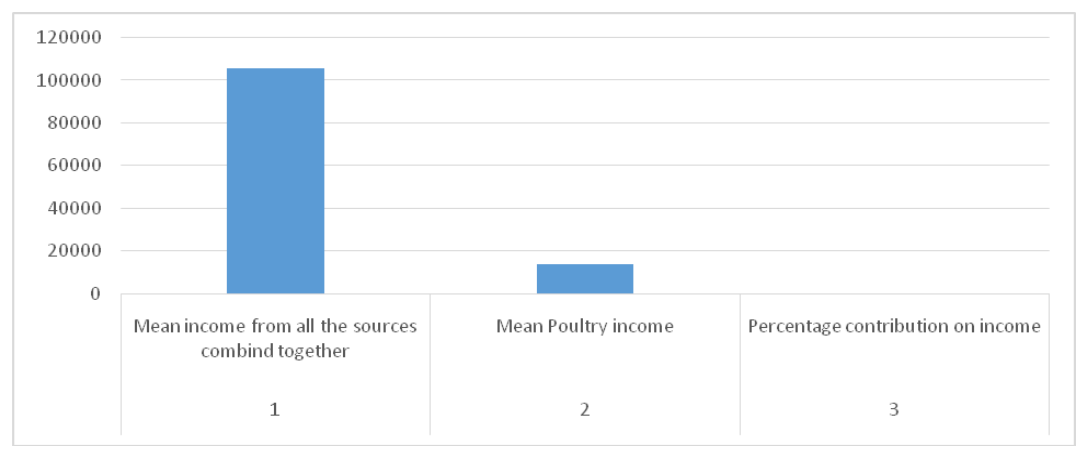

\section{Nutritional security ensured by the Fixed assets possessed by the respondents consumption of poultry product for backyard poultry farming}

In rural areas of Jharkhand the average family keeps the poultry birds and, therefore, the researcher found it pertinent to calculate the extent of nutritional security ensured by poultry product. Nutritional security ensured by the consumption of poultry products is presented in Table 3 and Fig 3.

It is indicated by the table and fig that the respondents' family had the energy gap of 28 , 81,802 kcal per month and the poultry supplemented 13, 27, $000 \mathrm{kcal}$ per month. Even then final energy gap was found to be $15,54,802 \mathrm{kcal}$ per month which is a matter of concern.

Hence, the stakeholders should be apprised about the nutritional status of the farming community and policy should be formulated to bridge the nutritional gap.

\section{Income from backyard poultry farming}

To calculate income from backyard poultry farming, detailed economic analysis has been done. Fixed asset possessed by the respondents, economics of backyard poultry production and income contribution from backyard poultry farming have been explained under this heading.
It is common knowledge that that the farmers need not make an infrastructure for backyard poultry farming. However, the researcher found that farmers created some infrastructure for backyard poultry farming.

It is revealed by Table 4 that for a flock size of 25 birds, a farmer has to invest Rs. 6000.00 for constructing a bamboo house. On an average, the poultry farmer keeps 3 feeding and watering equipment at the cost of Rs. 450.00. Thus altogether a farmer invests Rs. 6450.00 for creating fixed assets.

\section{Economics of backyard poultry farming}

Backyard poultry farming generates supplementary income for the family and is considered one of the sources of livelihood. The economics of backyard poultry farming of the flock size of 25 birds is presented in Table 5.

It is indicated by the table that the farmers incurred Rs. 2235.00 as fixed cost which comprised depreciation on bamboo housing (Rs. 1500.00), interest on bamboo housing (Rs. 600.00), depreciation on feeding and watering equipment (Rs. 90.00) and interest on feeding and watering equipment (Rs. 45.00). The variable expenditure included 
cost of chicks (Rs. 1625.00), feeding cost (Rs. 9500.00), and cost on vaccination (Rs. 200.00). The total expenditure under variable cost was computed to be Rs. 11325.00. On an average, a hen lays 135 eggs per year, thus from flock size of 25 birds the total eggs will be 3375 which in local market are sold at the Rs. 10.00 per egg, thus the total return from egg is computed to be Rs. 33750.00. Farmers generally sell their birds after a year. The customers have preference for Desi birds which are sold at premium price at the Rs. 300.00 per bird, hence the return from sale of birds was computed to be Rs. 7500.00. The return from poultry manure was computed to be Rs. 5000.00 per annum. The gross return from the backyard poultry farming was calculated to be Rs. 46250.00 and net return Rs. 32690.00. The net return from per bird was found to be Rs. 1360.00. Benefit-cost ratio was computed to be 3.41 which shows that backyard poultry farming is a remunerative venture.

The findings are in conformity with those of Islam et al., (2015), Krishna and Gurram (2017) and Yadav et al., (2016).

\section{Income contribution from backyard poultry farming}

Every smaller enterprise at the farmers' field has complimentary and supplementary role. It was thought prudent to compute the contribution from backyard poultry farming towards total income which is presented in Table 5 and Fig. 4.

The table and fig show that the mean annual income of the respondents combining all the sources was Rs. 1, 05, 800.00 in which income from backyard poultry farming was Rs.13700.00 which constitutes $14.84 \%$ of total income.

The findings give enough cue to devise appropriate strategies for promotion of backyard poultry farming so that the goal of doubling farmers' income by 2022 could be easily achieved.

In conclusion the analysis of nutritional security revealed alarming situation and the family consumption in almost all the food items fell short of recommendations. Still, the findings raise hope that calorie deficit can be well bridged by the promotion of backyard poultry farming. Economic analysis amply makes it clear that backyard poultry farming contributes about $15 \%$ towards total income. The findings give strong cue that nutritional and income security of rural people can be ensured through promotion of backyard poultry farming.

\section{References}

Baruah, M.S. and Raghav, C.S. (2017). Viability and economics of backyard poultry farming in West Siang District of Arunachal Pradesh, India. International Journal of Food Agriculture and Veterinary Sciences 7(1): 9-14.

Ekunwe, P.A., Fabge, O., Oyedeji, J.O. and Emokaro, C.O. (2010). Economics of backyard poultry production in Akure South local government area of Ondo State, Nigeria. Ghana Jnl Agric. Sci. 42:15-23.

Gangwar, L. S., Saran, S., and Kumar, S. (2013). Integrated poultry-fish farming systems for sustainable rural livelihood security in Kumaon hills of Uttarakhand. Agricultural Economics Research Review. 26(Conference): 181188.

Islam, R., Nath P. Bharali, A. and Borah, R. (2015). Analysis of benefit cost ratio of vanraja and local chicken of Assam under Backyard system of rearing. Journal of Research in Agriculture and 
Animal Science 3(7): 7-10.

Jensen .H A. and Dolberg F. (2003). Essentials and constraints - Adaptation of the Bangladeshi smallholder poultry development concept. Paper presented at the workshop on "Management of research, communication and change within Agricultural Sector Programmes", held at Tune, Denmark, 31 March - 4 April. pp 5.

Jha, B.K. and Chakrabarti, A. (2017).Backyard poultry farming as a source of livelihood in tribal village: An economic appraisal. International Journal of Agricultural Science and Research 7(1): 267-274.

Krishna, D., and Gurram, S. (2017).Impact of rearing backyard poultry on the food security and economic status of under privileged sections in Nalgonda District of Telangana State. International Journal of Livestock Research. 8(2):121-129.

Mack, N., Woodsong, C., Macqueen, K. M., Guest, G. and Namey, E. (2005). Qualitative Research Methods: A Data
Collector's Field Guide. Family Health International, North Carolina, USA.

Maikasuwa, M. A., and Jabo, M. S. M. (2011). Profitability of backyard poultry farming in Sokoto Metropolis, Sokoto State, North-West, Nigeria. Nigerian Journal of Basic and Applied Sciences 19(1): 111-115.

Pica-Ciamarra, U. and Otte, J. (2010). Poultry, food security and poverty in India: Looking beyond the farm-gate. World's Poultry Science Journal, 66(2): 309-320

Singh, P., Dhillon, G. S., and Dhaliwal, A. P. S. (2020). Supplementing rural families through backyard poultry system in Bathinda District of Punjab (India). Int. J. Curr. Microbiol. App. Sci.9(3):1016.

Yadav, C.M., Bugalia, H.L., Ramawtar, Dadheech, S. and Dhakar, B. (2018). Economic of pratapdhan poultry under backyard system rearing in Bhilwara District of Rajasthan Int. J. Curr. Microbiol. Appl. Sci. 7(8): 4242-4246.

\section{How to cite this article:}

Pushp Gautam, M. K. Barnwal and B. K. Jha, Shweta Kumari and AnupKumar. 2021. Nutritional and Income Security through Backyard Poultry Farming. Int.J.Curr.Microbiol.App.Sci. 10(02): 331-338. doi: https://doi.org/10.20546/ijcmas.2021.1002.038 